\title{
Prevalence of pica among children attending pediatrics clinic at El-Menoufiya university hospital
}

\author{
Fathia Mohamed El nemer ${ }^{1}$, Doaa Mahmoud Alian ${ }^{1}$, Mona Salah Eldin ${ }^{1}$, \\ Housam Eldin Moustafa Khali1 ${ }^{1,2, *}$ \\ ${ }^{1}$ Department of Pediatrics, Faculty of medicine, Menoufiya University, Menoufiya, Governorate, Shebin El Koum city, Egypt \\ ${ }^{2}$ Researcher in pediatrics, Faculty of medicine, Menoufiya University, Address: Al Mahala -Gharbia governorate, Egypt
}

\section{Email address:}

housam8081@yahoo.com (H. E. M. Khalil)

\section{To cite this article:}

Fathia Mohamed El nemer, Doaa Mahmoud Alian, Mona Salah Eldin, Housam Eldin Moustafa Khalil. Prevalence of Pica Among Children Attending Pediatrics Clinic At El-Menoufiya University Hospital. American Journal of BioScience. Vol. 2, No. 4, 2014, pp. 147-152. doi: 10.11648/j.ajbio.20140204.15

\begin{abstract}
Objectives: to highlight the epidemiology of pica among children attending paediatrics outpatient clinic of Menoufiya university hospital. Background: Pica is a persistent eating of non-nutritive substance, which is inappropriate to the developmental level. Numerous etiologies have been proposed to explain pica. Different forms of pica are associated with a high rate of complications and substantial morbidity and mortality. Methods: The prospective study was undertaken at a pediatric outpatient clinic of Menoufiya university hospital. The mothers were interviewed and data were collected. General physical, systemic examination and investigations were done. Anemia was defined as haemoglobin thresholds for age (0.5-4.99 years) is $11 \mathrm{~g} / \mathrm{dl}$ and $11.5 \mathrm{~g} / \mathrm{dl}$ for age (5.00-11.99 years). Iron depletion was defined as serum ferritin levels of $<15 \mathrm{ng} / \mathrm{ml}$. And iron deficiency as serum iron level $<50 \mu \mathrm{g} / \mathrm{dl}$. Hypozincaemia was defined as serum zinc level of $<0.6$ $\mathrm{mg} / \mathrm{L}$. Results: From two thousands and four hundreds children visited pediatrics clinic, of them one hundred and seventy four patients of them were suffering from pica (prevalence of pica was $7.2 \%$ ). Clay was the material used by $43.1 \%$ children (major form of pica in this study) followed by Dust $(25.9 \%$ ) followed by paper and cigarette (both $4 \%$ ). The hemoglobin and serum iron levels, serum ferritin and serum zinc were below the reference range. Conclusion: Prevalence of pica is higher in males, four years or less age, rural residents, bottle feeders, poor nourished children, children came from low socioeconomic families, illiterate housewife mothers. Children with pica had low level of zinc, hemoglobin, iron and ferritin, which confirmed that there is a relationship between pica and iron deficiency anemia and / or hypozincaemia. The children who practice pica are prone to worm infestation.
\end{abstract}

Keywords: Anemia, Clay, Hypozincaemia, Iron, Pica, Prevalence

\section{Introduction}

Pica involves is the persistent eating of nonnutritive substances (e.g., plaster, charcoal, clay, wool, ashes, paint, and earth). The eating behaviour is inappropriate to the developmental level (e.g., the normal mouthing and tasting of objects in infants and toddlers) and not part of a culturally sanctioned practice ${ }^{[1]}$.

Available evidence suggests that the prevalence of pica eating varies widely across diverse social and clinical contexts and appears to be higher among select populations that include pregnant women, children, and adults with iron deficiency and institutionalized persons ${ }^{[2]}$.

Numerous aetiologies have been proposed, ranging from psychosocial causes to physical ones. They include nutritional deficiencies (e.g., iron, zinc, and calcium), low socioeconomic factors, child abuse and neglect, family disorganisation (e.g., poor supervision), psychopathology, learned behaviour, underlying (but undetermined) biochemical disorder, and cultural and familial factors ${ }^{[1]}$.

Geophagia and other forms of pica are associated with a high rate of complications and substantial morbidity and mortality. Pica effects can be classified into five groups: inherent toxicity (such as lead), obstruction, excessive calorie intake, nutritional deprivation and parasitic infections ${ }^{[3-4]}$. 


\section{Materials and Methods}

This prospective study was undertaken at a pediatric outpatient clinic of Menoufiya university hospital from November 2012 to April 2014.From two thousands and four hundreds children visited pediatrics clinic, of them one hundred and seventy four patients of them (7.2\%) more than 18 months old visiting this clinic suffering from pica and those were participated in this study. Parent's consent was obtained and privacy of children was achieved and no any risk from this study.

- Inclusion criteria:

- Children attending the pediatric outpatient clinic of Menoufiya university hospital suffering from pica as direct or indirect complaint.

- Age more than 18 months old.

Exclusion criteria:

- Mental retarded children.

- Children less than 18 months old.

These patients were divided into two groups:

- Group I: (direct pica) patient's mothers gave direct history of abnormal feeding behaviour (pica).

- Group II: (indirect pica) patient's mothers gave indirect history of pica (as a leading question) that their main complaint was abdominal pain, vomiting, diarrhea, sore throat and etc in presence of abnormal feeding behaviour.

All patients were subjected to the following:

1. Full History taking

2. Thorough Clinical Examination

3. The following investigations were done

Routine investigations and Specific investigations (serum iron - serum ferritin - serum zinc).

Anemia was defined as hemoglobin thresholds for age $(0.5-4.99$ years) is $11 \mathrm{~g} / \mathrm{dl}$ and $11.5 \mathrm{~g} / \mathrm{dl}$ for age $(5.00-11.99$ years). Iron depletion was defined as serum ferritin levels of $<15 \mathrm{ng} / \mathrm{ml}$. And iron deficiency as serum iron level $<50$ $\mu \mathrm{g} / \mathrm{dl}$. Hypozincaemia was defined as serum zinc level of $<0.6 \mathrm{mg} / \mathrm{L}$.

Results were collected and statistically analyzed by statistical package for social science (SPSS) version 20.

\section{Results}

The majority of cases were belonging to $36-48$ months $(39.1 \%)$ age group. With definite male predominance as males were represent $63 \%$. Pica was more in bottle-feed children as compared to breast-feed. Most this children (70.7\%) had poor nutritional status (Table 1$)$.

Pica was observed more in children living in rural areas $(79.3 \%)$. The majority of mothers had education status up to higher secondary. Pica was observed more in children of housewives mothers, commonly, with illiterate housewife mothers than educated ones . The majority of cases $(93.1 \%)$ had low socioeconomic status. Family history for pica was positive in $40.2 \%$ children (Table 2 ).
About $23.6 \%$ mothers gave direct history of pica. The other presenting complains were diarrhea $(25.3 \%)$, cough $(14.9 \%)$, abdominal pain $(10.3 \%)$, itching anus $(8.6 \%)$, poor appetite $(8.0 \%)$, sore throat $(5.2 \%)$ and vomiting $(4 \%)$ (Table 3).

Clay was the material used by $43.1 \%$ children followed by Dust (2 $5.9 \%$ ) followed by paper and cigarette (both $4 \%$ ) and least percentage is for stool, ice and hair (Figure 1).

There was no significant difference between studied groups as regard the material used by children in pica (Table 4).

The majority of children had haemoglobin, serum iron, ferritin and zinc below reference values. With mean hemoglobin $9.7 \mathrm{~g} / \mathrm{dl}$ (SD 1.5) , mean iron $154.51 \pm$ $32.77 \mu \mathrm{g} / \mathrm{dl}$, mean ferritin $14.24 \pm 16.13 \mathrm{ng} / \mathrm{ml}$ and mean zinc $0.45 \pm 0.08 \mathrm{mg} / \mathrm{L}$. Majority of cases had parasitic infections (79.9 \%) of which Ascaris was the most common form of infection (28.7\%) (Table 5).

There was no significant difference between studied groups as regard their laboratory investigations (Table 6).

Hemoglobin level was highly significant low in clay than paper eaters $\&$ in dust than paper eaters, serum iron level was significant low in clay than paper eaters \&in dust than papers eaters and serum ferritin level was significant low in clay than paper eaters \& in dust than papers eaters (Table 7).

Highest prevalence of parasite infection was showed in mixed materials eaters followed by clay eaters. And Ascaris was the most common parasite incriminated in clay eaters (Table 8).

Table 1. Distribution of the studied children regarding their characteristics.

\begin{tabular}{lll}
\hline & $\mathbf{N}=\mathbf{1 7 4}$ & $\mathbf{\%}$ \\
\hline Age & & \\
$\leq 24$ & 22 & 12.6 \\
$>24-36$ & 63 & 36.2 \\
$>36-48$ & 68 & 39.1 \\
$>48-60$ & 2 & 1.1 \\
$>60$ & 19 & 10.9 \\
Mean \pm SD (months) & $39.33 \pm 12.07$ & \\
Median & 37 & \\
Range & $20-72$ & \\
Sex & & 63.2 \\
Male & 110 & 36.8 \\
Female & 64 & \\
Feeding & & 29.9 \\
Breast & 52 & \\
Bottle : & & 50.6 \\
Cow milk & 88 & 19.5 \\
Powder milk & 34 & 70.7 \\
Nutrition & & 29.3 \\
Poor & 123 & \\
Good & 51 & \\
\hline
\end{tabular}

Table 2. Distribution of the studied children regarding their mother's characteristics.

\begin{tabular}{lll}
\hline & $\mathbf{N}=\mathbf{1 7 4}$ & $\mathbf{\%}$ \\
\hline Residence & & \\
Urban & 36 & 20.7 \\
Rural & 138 & 79.3 \\
Mother's education & & \\
\hline
\end{tabular}




\begin{tabular}{lll}
\hline & $\mathbf{N = 1 7 4}$ & $\mathbf{\%}$ \\
\hline Illiterate & 66 & 37.9 \\
Secondary & 100 & 57.5 \\
Academic & 8 & 4.6 \\
Mother's occupation & & \\
Housewife : & 127 & 72.9 \\
1) Illiterate & 66 & 51.9 \\
2)Secondary & 57 & 44.8 \\
3)Academic & 4 & 3.1 \\
Working : & 47 & 27.1 \\
1)Secondary & 43 & 91.4 \\
2)Academic & 4 & 8.5 \\
Socioeconomic status & & \\
Low & 162 & 93.1 \\
High & 12 & 6.9 \\
Family history of pica & & \\
Yes & 70 & 40.2 \\
No & 104 & 59.8 \\
\hline
\end{tabular}

Table 3. Distribution of the studied children regarding the type of pica.

\begin{tabular}{lll}
\hline Complaint & $\mathbf{N}=\mathbf{1 7 4}$ & $\mathbf{\%}$ \\
\hline Pica (Direct) & 41 & 23.6 \\
Indirect: & 133 & 76.4 \\
Cough & 26 & 14.9 \\
Abdominal pain & 18 & 10.3 \\
Itching anus & 15 & 8.6 \\
Poor appetite & 14 & 8.0 \\
Diarrhea & 44 & 25.3 \\
Vomiting & 7 & 4.0 \\
Sore throat & 9 & 5.2 \\
\hline
\end{tabular}

Table 4. Comparison between the studied groups regarding the type of material of pica.

\begin{tabular}{|c|c|c|c|c|c|c|}
\hline \multirow{3}{*}{ Material } & \multicolumn{4}{|c|}{ Pica } & \multirow{3}{*}{$\mathrm{Z}$ test } & \multirow{3}{*}{ P value } \\
\hline & \multicolumn{2}{|c|}{$\begin{array}{l}\text { Group } 1 \\
(n=41)\end{array}$} & \multicolumn{2}{|c|}{$\begin{array}{l}\text { Group 2 } \\
(n=133)\end{array}$} & & \\
\hline & no & $\%$ & no & $\%$ & & \\
\hline Clay & 16 & 39.0 & 59 & 44.4 & 0.43 & 0.667 \\
\hline Dust & 8 & 19.5 & 37 & 27.8 & 0.86 & 0.391 \\
\hline Paper & 3 & 7.3 & 4 & 3.0 & 0.77 & 0.440 \\
\hline Cigarette & 3 & 7.3 & 4 & 3.0 & 0.77 & 0.440 \\
\hline Stool & 9 & 22.0 & 25 & 18.8 & 0.23 & 0.820 \\
\hline Ice & 0 & 0.0 & 2 & 1.5 & 0.05 & 0.959 \\
\hline Hair & 0 & 0.0 & 2 & 1.5 & 0.05 & 0.959 \\
\hline Mixed materials & 2 & 4.9 & 0 & 0.0 & 0.33 & 0.740 \\
\hline
\end{tabular}

Table 5. Distribution of the studied children regarding their lab investigations.

\begin{tabular}{|c|c|c|}
\hline & Number $=174$ & $\%$ \\
\hline \multicolumn{3}{|l|}{ Hemoglobin(gm/dl)* } \\
\hline $\mathrm{HB} \geq 11$ (children $<5 \mathrm{yrs}$ ) & 25 & 14.36 \\
\hline $\mathrm{HB} \geq 11.5$ (children $>5 \mathrm{yrs})$ & 3 & 1.72 \\
\hline $\mathrm{HB}<11$ (children $<5 \mathrm{yrs})$ & 128 & 73.56 \\
\hline $\mathrm{HB}<11.5$ (children $\geq 5 \mathrm{yrs})$ & 18 & 10.34 \\
\hline Range & $6.70-12.80$ & \\
\hline Mean \pm SD & $9.70 \pm 1.53$ & \\
\hline \multicolumn{3}{|l|}{$\operatorname{Iron}(\mu \mathrm{g} / \mathrm{dl})$} \\
\hline$<50$ & 146 & 83.9 \\
\hline$\geq 50$ & 28 & 16.1 \\
\hline Range & $35.60-139.10$ & \\
\hline Mean \pm SD & $54.51 \pm 32.77$ & \\
\hline \multicolumn{3}{|l|}{ Ferritin( $\mathrm{ng} / \mathrm{ml})$} \\
\hline$<12$ & 146 & 83.9 \\
\hline$\geq 12$ & 28 & 16.1 \\
\hline Range & $4.20-55.10$ & \\
\hline Mean \pm SD & $14.24 \pm 16.13$ & \\
\hline \multicolumn{3}{|l|}{ Zinc $(\mathrm{mg} / \mathrm{L})$} \\
\hline$<0.6$ & 156 & 89.66 \\
\hline$\geq 0.6$ & 18 & 10.34 \\
\hline Range & $0.36-0.70$ & \\
\hline Mean \pm SD & $0.45 \pm 0.08$ & \\
\hline \multicolumn{3}{|l|}{ Parasite } \\
\hline No parasite & 35 & 20.1 \\
\hline \multicolumn{3}{|l|}{ Parasite } \\
\hline Total & 139 & 79.7 \\
\hline \multicolumn{3}{|l|}{ Differential } \\
\hline E.histolytica & 28 & 16.1 \\
\hline E.vermicularis & 20 & 11.5 \\
\hline Ascaris & 59 & 28.7 \\
\hline Giardia & 6 & 3.4 \\
\hline Mixed infection & 35 & 20.1 \\
\hline
\end{tabular}

$\mathrm{HB}=$ haemoglobin \& E. histolytica = Entameba histolytica \& $\mathrm{E}$. vermicularis $=$ Enterobius vermicularis

* $\mathrm{Hb}$ thresholds for age ( $0.5-4.99$ years): $11 \mathrm{~g} / \mathrm{dl}$ and ( $5.00-11.99$ years): $11.5 \mathrm{~g} / \mathrm{dl}$.

Table 6. Comparison between the studied groups regarding their laboratory investigations.

\begin{tabular}{|c|c|c|c|c|c|c|}
\hline & \multicolumn{4}{|c|}{ Pica } & \multirow{3}{*}{ Test of significance } & \multirow{3}{*}{ P value } \\
\hline & \multicolumn{2}{|c|}{$\begin{array}{l}\text { Group } 1 \\
(n=41)\end{array}$} & \multicolumn{2}{|c|}{$\begin{array}{l}\text { Group 2 } \\
(\mathrm{n}=133)\end{array}$} & & \\
\hline & no & $\%$ & no & $\%$ & & \\
\hline $\mathrm{Hb}($ mean $\pm \mathrm{SD})$ & \multicolumn{2}{|c|}{$9.75 \pm 1.49$} & \multicolumn{2}{|c|}{$9.69 \pm 1.55$} & $\mathrm{t}=0.21$ & 0.829 \\
\hline Iron (mean $\pm \mathrm{SD}$ ) & \multicolumn{2}{|c|}{$55.42 \pm 33.26$} & \multicolumn{2}{|c|}{$54.23 \pm 32.74$} & $\begin{array}{l}\text { Mann-Whitney } \\
0.18\end{array}$ & 0.855 \\
\hline Ferritin $($ mean $\pm \mathrm{SD})$ & \multicolumn{2}{|c|}{$14.76 \pm 16.36$} & \multicolumn{2}{|c|}{$14.08 \pm 16.12$} & $\begin{array}{l}\text { Mann- Whitney } \\
0.22\end{array}$ & 0.826 \\
\hline Zinc (mean \pm SD) & \multicolumn{2}{|c|}{$0.43 \pm 0.06$} & \multicolumn{2}{|c|}{$0.46 \pm 0.09$} & $\mathrm{t}=0.76$ & 0.454 \\
\hline Parasite & & & & & $\mathrm{Z}$ & \\
\hline E.histolytica & 8 & 19.5 & 20 & 15.0 & 0.44 & 0.657 \\
\hline E.vermicularis & 3 & 7.3 & 17 & 12.8 & 0.69 & 0.493 \\
\hline Ascaris & 14 & 34.1 & 36 & 27.1 & 0.67 & 0.503 \\
\hline Giardia & 3 & 7.3 & 3 & 2.3 & 1.04 & 0.294 \\
\hline Mixed infection & 8 & 19.5 & 27 & 20.3 & 0.11 & 0.911 \\
\hline Free & 5 & 12.2 & 30 & 22.6 & 1.23 & 0.219 \\
\hline
\end{tabular}


Table 7. Comparison between laboratory investigations of studied groups regarding the type of material of pica.

\begin{tabular}{|c|c|c|c|c|c|c|c|}
\hline & Clay & Dust & Paper & Cigarette & Mixed & & \\
\hline Lab & $\begin{array}{l}\text { Mean } \\
\pm \text { SD }\end{array}$ & Mean \pm SD & $\begin{array}{l}\text { Mean } \\
\pm \text { SD }\end{array}$ & $\begin{array}{l}\text { Mean } \\
\pm \text { SD }\end{array}$ & $\begin{array}{l}\text { Mean } \\
\pm \text { SD }\end{array}$ & Kruskal-Wallis & Post hoc test \\
\hline $\mathrm{Hb}$ & $\begin{array}{c}9.14 \\
\pm 1.29\end{array}$ & $\begin{array}{l}10.08 \\
\pm 1.53\end{array}$ & $\begin{array}{l}11.74 \\
\pm 0.55\end{array}$ & $\begin{array}{l}11.34 \\
\pm 1.29\end{array}$ & $\begin{array}{l}9.62 \\
\pm 1.44\end{array}$ & $\begin{array}{c}10.33 \\
<0.001\end{array}$ & $\begin{array}{c}<0.05 \text { CL,D-CL,C) } \\
<0.001(\mathrm{CL}, \mathrm{P}-\mathrm{D}, \mathrm{P}-\mathrm{P}, \mathrm{M})\end{array}$ \\
\hline Iron & $\begin{array}{c}42.67 \\
\pm 13.89\end{array}$ & $\begin{array}{c}60.52 \\
\pm 38.09\end{array}$ & $\begin{array}{l}113.74 \\
\pm 32.05\end{array}$ & $\begin{array}{c}94.32 \\
\pm 50.16\end{array}$ & $\begin{array}{l}49.07 \\
\pm 26.66\end{array}$ & $\begin{array}{l}29.60 \\
P<0.001\end{array}$ & $<0.05$ CL,D-CL,P- D,P- P,M) \\
\hline Ferritin & $\begin{array}{c}8.20 \\
\pm 7.35\end{array}$ & $\begin{array}{c}17.45 \\
\pm 18.80\end{array}$ & $\begin{array}{c}43.75 \\
\pm 15.42\end{array}$ & $\begin{array}{c}33.18 \\
\pm 23.21\end{array}$ & $\begin{array}{l}8.04 \\
\pm 2.0\end{array}$ & $\begin{array}{l}29.55 \\
<0.001\end{array}$ & $<0.05$ CL,D-CL,P- D,P- P,M-M,D \\
\hline Zinc & $\begin{array}{c}0.50 \\
\pm 0.06\end{array}$ & $\begin{array}{c}0.42 \\
\pm 0.03\end{array}$ & - & $\begin{array}{c}0.41 \\
\pm 0.02\end{array}$ & $\begin{array}{c}0.38 \\
\pm 0.02\end{array}$ & $\begin{array}{l}\mathrm{F}=5.27 \\
\mathrm{P}=0.012\end{array}$ & $\begin{array}{c}<0.001(\mathrm{CL}, \mathrm{D}-\mathrm{CL}, \mathrm{C}-\mathrm{M}, \mathrm{C}) \\
<0.05(\mathrm{D}, \mathrm{C})\end{array}$ \\
\hline
\end{tabular}

$\mathrm{CL}=$ clay, $\mathrm{D}=$ dust, $\mathrm{C}=$ cigarette, $\mathrm{P}=$ paper, $\mathrm{M}=$ mixed materials, $\mathrm{HB}=$ hemoglobin Significant difference if $\mathrm{P}<0.05$

Highly significant difference if $\mathrm{P}<0.001$

Non-significant difference if $\mathrm{P}>0.05$

Table 8. Distribution of the studied material groups regarding the parasitic infection.

\begin{tabular}{|c|c|c|c|c|c|c|c|c|c|c|}
\hline \multirow{2}{*}{ Parasitic infection } & \multicolumn{2}{|c|}{ Clay } & \multicolumn{2}{|c|}{ Dust } & \multicolumn{2}{|c|}{ Paper } & \multicolumn{2}{|c|}{ Cigarette } & \multicolumn{2}{|c|}{ Mixed materials } \\
\hline & no & $\%$ & no & $\%$ & no & $\%$ & no & $\%$ & no & $\%$ \\
\hline No parasite & 11 & 14.6 & 12 & 26.7 & 4 & 57.1 & 3 & 42.9 & 3 & 8.8 \\
\hline Parasite: & & & & & & & & & & \\
\hline $\begin{array}{l}\text { Total } \\
\text { differential }\end{array}$ & 64 & 85.4 & 33 & 73.3 & 3 & 42.9 & 4 & 57.1 & 31 & 91.2 \\
\hline E.histolytica & 18 & 24.0 & 5 & 11.1 & 1 & 14.3 & 1 & 14.3 & 3 & 8.8 \\
\hline E.vermicularis & 9 & 12.0 & 6 & 13.3 & 0 & 0.0 & 0 & 0.0 & 3 & 8.8 \\
\hline Ascaris & 20 & 26.7 & 14 & 31.1 & 0 & 0.0 & 1 & 14.3 & 14 & 41.2 \\
\hline Giardia & 3 & 4.0 & 2 & 4.4 & 1 & 14.3 & 0 & 0.0 & 0 & 0.0 \\
\hline Mixed infection & 14 & 18.7 & 6 & 13.3 & 1 & 14.3 & 2 & 28.6 & 11 & 32.4 \\
\hline
\end{tabular}

E. histolytica $=$ Entameba histolytica \& E. vermicularis $=$ Enterobius vermicularis.

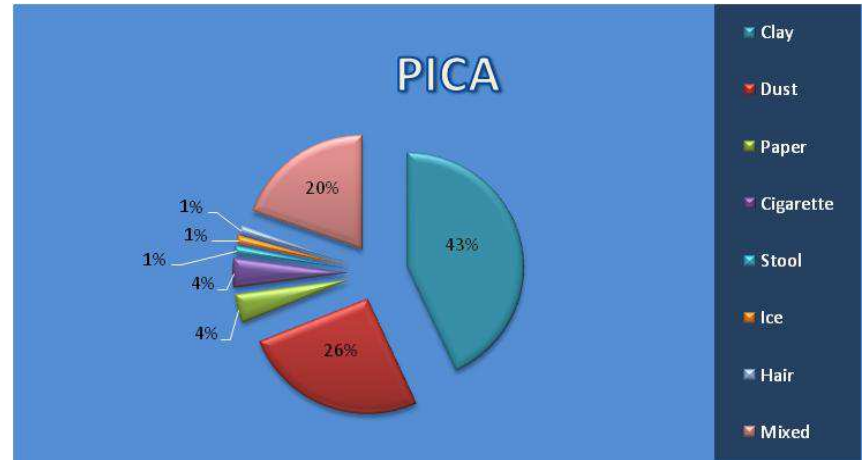

Fig. 1. Distribution of the studied children regarding the type of material of pica.

\section{Discussion}

Pica is the persistent eating of nonnutritive substances. The eating behaviour is inappropriate to the developmental level and not part of a culturally sanctioned practice [1].

Although prevalence rates vary depending on the definition of pica, the characteristics of population sample and the methods used for data collection, pica is reported most commonly in children [5].

Estimations have varied widely within a particular population, depending on the criteria used [4]. Therefore, the approach used in this study was to assess and declare the epidemiology of pica among children attending the pediatrics outpatient clinic of Menoufiya university hospital.

Our prospective study was undertaken at the pediatrics outpatient clinic of Menoufiya university hospital. From two thousands and four hundreds children visited pediatrics clinic, of them one hundred and seventy four patients of them suffering from pica (prevalence of pica was $7.2 \%$ ) in contrast to $11.5 \%$. in Al-Sawaf study [6].

However the prevalence of pica has been reported to vary from one region to another among African countries [7].

In the present study, the age of children suffering from pica ranged from (20-72months). The majority of children were 4 years or less $(87.9 \%)$. Regarding gender, 110 (63.2\%)of patients were males and 46 (36.8\%) were females with definite male predominance.

Our results, regarding the presenting age and gender was almost similar to other studies [5-6].

Regarding feeding, pica was more in bottle-feed (cow and powder milk) (70.1\%) children as compared to breast-feed $(29.9 \%)$ and this is not in agreement with Ravinder and Ritu study [5].

Majority of children (70.7\%) in our study had poor nutritional status, similar findings were found by Al-Sawaf [6]. This nutritional deprivation is imposed on the children by eating substances instead of nutritive foods. 
In the present study, pica was observed more in children living in rural areas $(79.3 \%)$ rather than children living in urban area $(20.7 \%)$. The majority of mothers had education status up to higher secondary school $(57.5 \%)$ as compared to illiterate (37.9\%) and academic status (4.6\%). Family history for pica was positive in $40.2 \%$ children, and this is in agreement with Ravinder and Ritu study [5]. As members of family exposed to the same environmental, psychological and nutritional risks.

Regarding mother's occupation, the pica was observed more in children of housewife mothers $(72.9 \%)$ as compared to working mothers $(27.1 \%)$ and the majority of housewife mothers $(51.9 \%)$ were illiterate while majority of working mothers $(91.4 \%)$ attending up to high secondary schools which reflect the role of ignorance and illiteracy in pica.

The majority of cases $(93.1 \%)$ had low socioeconomic status, similar to other study in Iraq [6].

Regarding clinical presentation, group I (direct pica) whom patient's mothers gave direct history of abnormal feeding behaviour was represent $(23.6 \%)$ and group II (indirect pica) whom patient s mothers gave indirect history of pica (as a leading question) was represent majority of children (76.4\%), almost similar to Ravinder and Ritu study [5].

Pica is a risk factor for diarrhea in the home environment and explanation is that children are likely to defecate indiscriminately and their faecal matter is likely to lie anywhere in the yard for some time before it is noticed by the mother/caretaker and children's excreta are more likely to contain diarrheal pathogens [8].

The majority of main complain in group II were diarrhea $(25.3 \%)$ followed by cough $(14.9 \%)$ followed by abdominal pain $(10.3 \%)$.

Clay eating is widespread in Africa with estimated prevalence level in the rural areas $90 \%$. This may be due to poor sanitation, bad hygiene, poverty and ignorance in rural areas [9]. In our study clay was the material used by majority of children suffering from pica ( $43.1 \%$ of children) followed by dust $(25.9 \%)$ followed by paper and cigarette (both $4 \%$ ) and least percentage is for stool, ice and hair with non significant difference between the studied groups.

This is in agreement with Ravinder and Ritu as clay was the material used by majority of children in their study and they reported that geophagia is the most common form of pica in people who live in poverty societies [5].

In the present study, the hemoglobin, serum iron levels, serum ferritin and serum zinc were below the reference range with non-significant difference between studied groups. The majority of children suffering from pica were anemic (83.9\%)with mean hemoglobin was $9.7 \mathrm{~g} / \mathrm{dl}$ (SD $1.5)$ and rang (6.70-12.80) and hemoglobin level was highly significant low in clay than paper eaters \& in dust than paper eaters. Regarding serum iron, $83.9 \%$ of children suffering from pica had serum iron less than normal reference with mean iron level $54.51 \mu \mathrm{g} / \mathrm{dl}$ and range (35.60-139.10) and serum iron level was significant low in clay than paper eaters \&in dust than papers eaters.
Regarding ferritin level, majority of children (83.9\%) had serum iron less than normal reference with mean level (14.24 $\pm 16.13 \mathrm{ng} / \mathrm{ml})$ and range (4.20-55.10) and serum ferritin level was significant low in clay than paper eaters \& in dust than papers eaters . Regarding serum zinc, $(89.66 \%)$ of children had low zinc level (normal value is $0.6-1.30$ $\mathrm{mg} / \mathrm{L})$ with mean zinc level of all children was $(0.45 \pm 0.08$ $\mathrm{mg} / \mathrm{L}$ ) and serum zinc level was highly significant low in dust than clay eaters. There was with no significant difference between studied groups regarding these laboratory findings.

This results is in agreement with Sunit et al., who found that mean hemoglobin, iron and zinc levels were significantly lower in children suffering from pica with hemoglobin level $8.5 \pm 1.3 \mathrm{~g} / \mathrm{dl}$ (range 6.5-11.5) ; iron level $42 . .7 \pm 9.2 \mu \mathrm{g} / \mathrm{dl}$ (range 30-67) and zinc level 0. $60 \pm 0.04$ $\mathrm{mg} / \mathrm{L}$ (range 0.53-0.70). [10]. Thus, pica results in malabsorption of iron and/or zinc from the diet with resultant strong association between hypozincemia, iron deficiency and pica.

Also in agreement with Al-Sawaf as the haemoglobin level was $9.5-11.5 \mathrm{gm} / \mathrm{dl}$ in $(34.38 \%)$ and it was $6.5-9$ $\mathrm{gm} / \mathrm{dl}$ in the remaining $65.62 \%$.The majority of them $91.25 \%$ had hypochromic microcytic anemia with dramatic response to iron therapy in all the patients in his study. So, pica has frequently been described as a symptom of iron deficiency [6].

In Ravinder and Ritu study, Initial hemoglobin levels were less than $8 \mathrm{gm} / \mathrm{dl}$ in $34.5 \%$ and $11 \mathrm{gms} / \mathrm{dl}$ or greater in $20 \%$ of pica children [5].

In the present study, majority of cases had parasitic infections (79.9\%) of which Ascaris is the most common form of infection $(28.7 \%)$.

This is an agreement with Ravinder and Ritu as intestinal parasites were identified in $63 \%$ of pica children in their study. Ascariasis, giardia lamblia, etc. were common parasites in their stools [5]. However, in developing countries, intestinal parasitism is also an indicator of substandard sanitation, poor personal hygiene, lack of a convenient, safe water source and poverty.

Several studies have linked geohelminths infection with soil consumption [9]. Our study reflects this association between geophagia and soil-transmitted helminthes, as most common form of parasite infection was Ascaris. However, A higher prevalence of Ascaris and this pattern of parasitism, indicates that geophagia is a specific risk factor for infection with orally acquired soil- transmitted nematode parasites.

\section{Conclusion}

Prevalence of pica is higher in males, four years or less age, rural residents, bottle feeders, poor nourished children, children came from low socioeconomic families, illiterate housewife mothers. Children with pica had low level of zinc, hemoglobin, iron and ferritin, which confirmed that there is a relationship between pica and iron deficiency 
anemia and / or hypozincaemia. The children who practice pica are prone to worm infestation

\section{References}

[1] Emily R and David R. Pica. In Robert M. Kliegman, Bonita F. Stanton, Joseph W. St.; et al. Nelson Textbook of pediaterics, 19th Edition. Saunders, an imprint of Elsevier Inc 2011;21(2): 70-72.

[2] Khan NZ, Ferdous S, Islam R ; et al . Behaviour problems in young children in rural Bangladesh. J Trop Pediatr 2009; 55(3): $177-182$.

[3] Alexader W. and Akos . Geophagia: the history of earth-eating. J R Soc Med 2002; 95:143-146.

[4] Edward A. R., John H. P., and Anne V. Pica Common but Commonly Missed. Journal of the American Board of Family Medicine 2000; 13(5): 353-358.
[5] Ravinder K. G and Ritu G. Clinical Profile of Pica in Childhood. JK Science 2005; 7:61-63.

[6] Al-Sawaf F B . Pica in children. Iraqi J Med Sci 2004; 3(2): 179-181.

[7] Ibrahim A . Pica in children with tetralogy of Fallot : Report of two cases. Muller J Med Sci Res 2013; 4:122-123.

[8] Moturi N. and Shivoga W A. Geophagia as a risk factor for diarrhea. J Infect Developing Countries 2009; 3(2): 94-98.

[9] Bisi-Johnson M A, Obi $\mathrm{C}$ L and Ekosse $\mathrm{G}$ E . Microbiological and health related perspectives of geophagia: An overview. African Journal of Biotechnology 2010; 9(19): 5784-5791.

[10] Sunit S , Ravishanker R , Pratibha S ; et al . Low Plasma Zinc and Iron in Pica. Indian Journal of Pediatrics 2003 ; $70: 139-142$. 